\title{
WŁADYSŁAW MARCEL ŻELEŃSKI
}

(1903-2006)

Pana Władysława znałam ponad trzydzieści lat. Był bratankiem Boya, wnukiem muzyka, Władysława Żeleńskiego, prawnikiem i dziennikarzem. Od 1939 roku wiceprokuratorem Sądu Apelacyjnego w Warszawie. W listopadzie 1939 roku we Francji walczył w kompanii karabinierów maszynowych i 1. Dywizji Grenadierów Polskich w Lotaryngii i Wogezach. Został odznaczony Srebrnym Krzyżem Zasługi z Mieczami i Croix de Guerre. Po kapitulacji Niemiec osiedlił się we Francji jako uchodźca polityczny. Pierwsze otrzymane od niego listy są z roku 1972. Ostatnie rozmowy telefoniczne — już z ciężko chorym panem Władysławem to początek roku 2006.

Rok 1972 rozpoczynający tę znajomość nie był przypadkowy. W kraju dobiegały końca prace nad Pismami zebranymi Tadeusza Żeleńskiego (Boya), ukazał się tom 27, a pod koniec roku również w Państwowym Instytucie Wydawniczym zostały wydane Listy Boya w moim opracowaniu. Pan Władysław z kolei kończył serię artykułów w „Wiadomościach” londyńskich poświęconych pamięci i obronie stryja, polemizując z negatywną oceną jego postawy wobec władz sowieckich podczas pobytu we Lwowie (1939-1941). Równocześnie przygotowywał skargę do władz zachodnioniemieckich, która spowodowała wznowienie umorzonego dochodzenia w sprawie mordu profesorów lwowskich. Korespondencja z tego okresu dotyczyła głównie tych spraw. Muszę przyznać, że prośby i zapytania pana Władysława wprowadzały mnie w duże zakłopotanie, miałam bowiem świadomość, że w mojej pracy doktorskiej Tadeusz Żeleński (Boy). Twórczość $i$ życie opublikowanej w roku 1967, lwowskie lata Boya wymagaja uzupełnień i poprawek, jednak brakowało mi wtedy czasu, ponieważ pracowałam nad obszernym kalendarium życia i twórczości Karola Irzykowskiego.

Przerwy pomiędzy naszymi listami były coraz dłuższe. Wprawdzie otrzymałam jeszcze wnikliwą ocenę wydanych Listów Boya i gratulacje za Obrachunki Boyowskie (antologię satyr i karykatur) oraz dołączony do listu indeks nierozwiązanych nazwisk „dla drugiego wydania”, którego mnie i sobie pan Władysław życzył. Jednak w przesyłanych kartkach okolicznościowych pojawiało się zapewnienie o zrozumieniu mojej ówczesnej sytuacji (chodziło o pracę nad pismami zebranymi Irzykowskiego dla Wydawnictwa Literackiego $)^{1}$.

W roku 1989, bez wcześniejszej zapowiedzi, przekazano mi paczkę z Paryża od pana Władysława. Znajdowały się w niej niezwykłe materiały: komplet artykułów poświęconych Boyowi z „Wiadomości” londyńskich, „Kultury” paryskiej i „Zeszytów Historycznych"; wystąpienia i publikacje dotyczące sprawy mordu profesorów lwowskich oraz publikowane wspomnienia i opinie przyjaciół i znajomych Tadeusza Żeleńskiego (Boya) o jego pobycie we Lwowie.

Nie miałam już wyboru, obok niedokończonego trzeciego tomu monografii o Irzykowskim znalazły się na moim biurku materiały o Boyu — nigdy tak blisko nie sąsiadowali skłóceni ze sobą dwaj najwybitniejsi polscy krytycy. Po trzech latach pracy, kontaktowania się z żyjącymi autorami wspomnień, dwukrotnym pobycie we Lwo-

\footnotetext{
${ }^{1} \mathrm{~W}$ ramach tej edycji opublikowano m.in. trzytomową monografię Karol Irzykowski: życie i twórczość (Kraków 1987-1994) autorstwa B. Winklowej.
} 
wie $\mathrm{z}$ aparatem fotograficznym i poszukiwaniu wydawcy, który bez dotacji podjąłby się wydania proponowanej mu antologii — książka ukazała się w roku 1992 nakładem Rytmu $^{2}$. Antologię tekstów o pobycie Tadeusza Żeleńskiego (Boya) we Lwowie, poprzedzał mój obszerny wstęp, zamykało kalendarium lwowskich miesięcy Boya, biogramy autorów wspomnień i mały album fotografii.

Książkę wręczyłam panu Władysławowi osobiście jesienią 1992 roku. Nie zapomnę tego pierwszego spotkania po dwudziestu latach znajomości. Szeroko otwartych drzwi i ramion pana Władysława witającego mnie w progu swojego mieszkania na 19 boulevard de la Somme Bât.B. Gościnny dom państwa Żeleńskich — Marii Adeli z Bohomolców (Mysi) i Władysław Marcelego — opisywano już wiele razy. Od siebie dodam tylko, że w tym domu z całą pewnością tak samo był przyjmowany Charles de Gaulle jak i mój piętnastoletni wnuk - obaj ciastkami z cukierni Bliklego na Nowym Świecie, czego nie omieszkał podkreślić pan Władysław.

W naszych wzajemnych kontaktach nastapiły zmiany. Pan Władysław tracił wzrok (kolejna operacja nie przyniosła poprawy), mniej ale jeszcze ciaggle czytał, z większym trudem pisał, więcej było rozmów telefonicznych, listy coraz krótsze. Pamiętam, jak długo bawiła go kartka urodzinowa, którą mu wysłałam z zacytowanymi życzeniami Kazimierza Tetmajera dla rodziców (Stanisława i Izy Żeleńskich) nowo narodzonego dziecka: „Winszuję chłopca i cieszę się, z niego, tą nadzieją, że nie będzie autorem Goplany, ani autorem Żniw ani autorem Podhala, czego Wam, jemu i sobie życzę. Amen" - napisał Tetmajer 11 lipca 1903 roku.

$\mathrm{Z}$ wielką radością powitał pan Władysław moją decyzję, ażeby ponownie opracować biografię Tadeusza Żeleńskiego tym razem uwzględniającą rodzinę i przyjaciół. Śledził jej losy, omawiał szczegółowo wszystkie rozdziały. Książka Nad Wisła i nad Sekwana została wydana w 1998 roku z inicjatywy Wiesława Uchańskiego prezesa Wydawnictwa Iskry, które mają swoją siedzibę w miejscu dawnego mieszkania Żeleńskich na ulicy Smolnej. W trakcie tej pracy nawiązały się bliskie kontakty prezesa z panem Żeleńskim, co z kolei zaowocowało wydaniem w Iskrach jego książki Zabójstwo ministra Pierackiego (Warszawa 1995).

W roku 1997 w wieku 100 lat umarła niespodziewanie pani Mysia. Rozmawiałam z nią w przeddzień śmierci, wieczorem, o promocji książki Żeleńscy, napisanej przez siostrzeńca pana Władysława - Zbigniewa Sroczyńskiego. Relacjonowałam to spotkanie, na którym książka oceniona została przychylnie. Następnego dnia rano pan Władysław zawiadomił mnie o śmierci żony. Była drugą żoną pana Władysława, poznał ją kiedy jeszcze nosiła mundur z wyższą od niego rangą. Oboje w równej mierze stwarzali niezwykły klimat swojego domu. Była znaną tłumaczką, m.in. przetłumaczyła na język francuski $\mathrm{Na}$ nieludzkiej ziemi Józefa Czapskiego ${ }^{3}$. W ich paryskim saloniku można było podziwiać piękne obrazy Czapskiego. Ponad dwadzieścia lat razem z mężem pracowała w zarządzie Towarzystwa Opieki nad Polskimi Grobami i Zabytkami Historycznymi we Francji. W 1993 została odznaczona Krzyżem Polonia Restituta. Po jej śmierci serdeczną opieką otoczyła pana Władysława zaprzyjaźniona z obojgiem pani Adela z Romerów Wysocka. Wróciły nasze telefoniczne rozmowy. Odnowienie kontaktów nastapiło po ukazaniu się w 1998 roku biografii Boya Nad Wista i nad Sekwana, którą pan Władysław, pomimo już bardzo słabego wzroku przeczytał

${ }^{2}$ Boy we Lwowie 1939-1941: antologia tekstów o pobycie Tadeusza Żeleńskiego (Boya) we Lwowie, w oprac. B. Winklowej, Warszawa 1992 (,Biblioteka Lwowska - Pokolenie, t. 9).

${ }^{3}$ J. Czapski, Terre inhumaine, traduit du polonais par M.-A. Bohomolec, Paris 1949; ponownie wydana w 1978 (Lausanne). 
dwukrotnie. Kiedy kolejny raz widzieliśmy się w Paryżu, był zajęty porządkowaniem swoich spraw, nie było już ogromnej biblioteki, mieszkanie straciło swój dawny blask. W rozmowach zaczęły dominować wspomnienia z młodości: studia, mieszkanie i mieszkańcy domu na Smolnej z okresu mieszkania u Boyów i Zosia z Wesela — żona Tadeusza, z którą się ogromnie lubili. Wtedy zrodziła się myśl, żeby tą piękną nietuzinkową postać utrwalić. Powstała książka Boyowie wydana w 2001 roku w Wydawnictwie Literackim w serii „Pary”. Wcześniej jednak przyjechałam do Paryża i przeczytałam ją cała panu Władysławowi przebywającemu w szpitalu. Spędziliśmy wiele godzin siedząc lub spacerując w przyszpitalnym ogrodzie. Pan Władysław poznał również moje dalsze zamierzenia cofnięcia się do XIX wieku, żeby tym razem przybliżyć matkę Tadeusza Żeleńskiego - Wandę z Grabowskich Żeleńską, najbliższą przyjaciółkę Narcyzy Żmichowskiej, której pudełko na cygara królowało na biurku stryja. Doczekał się i tej książki. Trzymał ją w ręku. Mówiono, że prosił aby mu ją czytać. Podczas ostatnich miesięcy życia rzadko odzyskiwał świadomość. Zmarł w dniu 25 czerwca 2006 roku.

Zdaję sobie sprawę, jak bardzo to wspomnienie jest osobiste, zawężone jedynie do naszych wspólnych spraw, ważnych — ale obejmujących ze 103-letniego bogatego i bardzo czynnego życia jedynie 30 ostatnich lat.

Zainteresowanych pełną biografią odsyłam do antologii Boy we Lwowie (Warszawa 1992), gdzie znajduje się biogram Władysława Żeleńskiego — jego autorstwa.

Barbara Winklowa (Warszawa) 